\title{
Evaluation of artemisinin-based combination therapy (ACT) to uncomplicated falciparum malaria patients in Purworejo District, Central Java, Indonesia
}

\author{
Michael Bhadi Bia ${ }^{1,2}$, E. Elsa Herdiana Murhandarwati ${ }^{3 *}$, Neil F Lobo ${ }^{4}$, William A \\ Hawley $^{5}$ Supargiyono ${ }^{3}$ \\ ${ }^{1}$ Post Graduate Program of Basic Medical and Biomedical Science of Faculty of \\ Medicine, Universitas Gadjah Mada, ${ }^{2}$ Politeknik Kesehatan Kementrian Kesehatan \\ Kupang, ${ }^{3}$ Department of Parasitology, Faculty of Medicine, Universitas Gadjah Mada, \\ ${ }^{4}$ Eck Institute for Global Health, University of Notre Dame, Notre Dame, IN 46556, \\ USA, ${ }^{5}$ UNICEF Jakarta, Indonesia
}

DOI: http://dx.doi.org/10.19106/JMedSci004801201605

\section{ABSTRACT}

Artemisinin-based Combination Therapy (ACT) to treat uncomplicated Plasmodium falciparum malaria has been applied in Purworejo District, Central Java, Indonesia, since 2004. However evaluation of the two ACT regimens used ie: Artesunate Amodiaquine $(A A Q)$ and Dihydroartemisinin-Piperaquine (DHP) co-administered with Primaquine (PQ) has not been performed. This study aims to evaluate the efficacy and adverse events of $\mathrm{AAQ}+\mathrm{PQ}$ and $\mathrm{DHP}+\mathrm{PQ}$ treatment in uncomplicated falciparum malaria in Purworejo. In this descriptive and observational study, 46 Pf infected patients who fullfill the inclusion and exclusion criterias were recruited from December 2010 to August 2011. Standard ACT treatment were given to the patients followed by WHO drug efficacy evaluation for 28 days. The clinical symptoms and adverse events was also evaluated over the course of the treatment. From all recruited subjects, 37 patients received DHP + $\mathrm{PO}$ and 9 patients received $A A Q+P Q$. On the $D H P+P Q$ treated patient, all subjects were free of asexual and sexual parasites by Day- 3 while on $A A Q+P Q$ treated patient, this parasite clearance was achieved faster as early as on D-2 at the latest. On the otherhand, the disappearance of fever was also last longer in DHP $+P Q$ treated patient which in one patient last on $D-14$, while in $A A Q+P Q$ treated patient, the symptom of fever dissappeared by D-2 at the latest. No Early or Late Treatment Failures were found on either DHP + PQ or $A A Q+P Q$ treatment as well as clinical and parasitological failures. However, the presence of adverse events cause by both drugs should not be ignored to ensure drug compliance. 


\section{ABSTRAK}

Terapi malaria dengan Artemisinin-based Combination Therapy (ACT) untuk malaria tanpa komplikasi diterapkan di Kabupaten Purworejo, Jawa, Indonesia, sejak tahun 2004. Namun demikian evaluasi terhadap efektivitas dua regimen ACT yang digunakan yaitu Artesunate Amodiakuin (AAQ) dan Dihydroartemisinin-Piperaquine (DHP) disertai Primakuin (PQ) belum pernah dilakukan. Penelitian ini bertujuan untuk mengevaluasi efikasi dan adverse events $\mathrm{AAO}+\mathrm{PO}$ dan $\mathrm{DHP}+\mathrm{PO}$ pada penderita malaria tanpa komplikasi di Purworejo. Penelitian ini merupakan penelitian deskriptif dan observasional. Subjek penelitian adalah pasien yang terinfeksi $P$. falciparum yang memenuhi kriteria inklusi dan eksklusi, direkrut dari Desember 2010 hingga Agustus 2011. Status resistensi obat, dan adverse events dievaluasi menggunakan cara evaluasi baku WHO selama 28 hari. Dari semua subjek yang direkrut (46), 37 penderita diobati dengan $\mathrm{DHP}+\mathrm{PO}$ dan 9 penderita dengan AAO $+\mathrm{PQ}$. Pada kelompok yang mendapat pengobatan $\mathrm{DHP}+\mathrm{PQ}$, semua subyek bebas dari parasit stadium aseksual dan seksual pada hari ke 3, sedangkan kelompok yang mendapatkan pengobatan $\mathrm{AAO}+\mathrm{PQ}$, parasit sudah menghilang dari sirkulasi darah pada hari-2. Semua penderita yang diobati $\mathrm{DHP}+\mathrm{PO}$ gejala demam menghilang lebih lama yaitu sampai hari ke 14, sedangkan pada penderita yang diobati dengan $A A Q+P O$ gejala demam sudah menghilang sejak hari ke 2 . Tidak ada kegagalan pengobatan dini maupun kegagalan pengobatan lanjut baik secara klinis maupun parasitologi pada penggunaan kedua obat tersebut. Walaupun demikian, adverse events sebaiknya tidak diabaikan untuk memastikan kepatuhan obat.

Keywords : falciparum malaria - artesunate + amodiaquine - dihydroartemisinin + piperaquine - treatment failure - adverse events

\section{INTRODUCTION}

Malaria remains a public health problem in more than 100 countries, including Indonesia. It is estimated that 300-500 million clinical cases occurs worldwide annually. ${ }^{1}$ Among four species of Plasmodium that infect humans, $P$. falciparum is the most virulent species and cause high morbidity and mortality ( 1 million per year). Malaria incidence in Indonesia had been reported to decline in the last decade. Compared to 2008, the Annual Parasite Incidence (API) in Indonesia in 2009 has decreased from 3.82 to 1.85 per million population. Java and Bali were classified as low endemic areas. However, despite of a continuous control measures malaria outbreaks have occurred sporadically in Indonesia in 2009, including Java Island. $^{2}$
Malaria control efforts in Indonesia have faced many constraints such as shortage of budgets, human resourse, insecticide-resistent vectors, ineffective intervention strategies and treatment failure due to parasite resistance to many antimalarial drugs. ${ }^{3}$ Parasite resistance is defined as the Plasmodium parasites ability to survive or proliferate within a theuraphetic or higher of the recommended dosage but still within patient tolerance. ${ }^{4}$ Based on the WHO and Indonesian Malaria Diagnosis Expert Committee (KOMLI), Artemisininbased combination therapy (ACTs) should be implemented in Indonesia in 2004. In Indonesia, there are currently two ACT regimens used in the malaria program i.e. artesunateamodiaquine (AAQ) and dihydroartemisininpiperaquine (DHP). Malaria parasite are known very adaptive and the reduction of 
sensitivity to anti malaria drug is predicted to appear along with the widespread use of ACT. ${ }^{5}$ The indication of the reduction of sensitivity of $P$. falciparum to AAQ/ DHP was reported by Hasugian et al. ${ }^{6}$ in Southern Papua, AAQ with treatment failure of $45 \%$ and treatment failure for DHP was 13\%.. Similar studies on AAQ resistance were also reported in Gabon, Ghana, Madagaskar, Rwanda, Sierra Leone, Zanzibar and Myanmar with treatment failure ranged from $8.7 \%$ to $27 \%$; and in Kenya the treatment failure of DHP was reported $8.3 \% .^{4}$

Purworejo is a district in Central Java that was classified as low-endemic areas in Indonesia. ${ }^{7}$ Incidence of malaria in Purworejo is influenced by several factors. These include. high mobility of people to and from disease endemic areas, geography, behavior of the population and also the presence of efficient malaria vector mosquitoes. ${ }^{8}$ Malaria control efforts were emphasized in 2002 by Gebrak Malaria programme that includes the strengthened on surveillance, vector control, and treatment. The success of this program was demonstrated by the decrease in malaria cases from 2002 to 2004. However, malaria cases have been increasing afterwards and outbreaks have been common in some villages ${ }^{9}$ starting in 2006.

Purworejo was confirmed as a region with multidrug resistance parasite ${ }^{10,11}$ in 2003, and therefore the used of ACT (ArtesunateLumefantrine, Coartem) was recomended to overcome treatment failure. ${ }^{12}$ When this study started in 2010, ACT regimen used in Purworejo were AAQ and DHP regimens. ${ }^{9}$ Evaluation of AAQ efficacy in Purworejo has been performed by Kusumaningsih. ${ }^{13}$ However, the AAQ used was without primaquine (PQ) as recommended. ${ }^{14}$ The results found that the AAQ treatment failure was $12.9 \%$, indicating reduced sensitivity to the AAQ that may cause malaria cases continue to appear.
Therefore, the objectives of this study were: 1. To evaluate the efficacy of $\mathrm{AAQ}+\mathrm{PQ}$ and $\mathrm{DHP}+\mathrm{PQ}$ on the treatment of uncomplicated falciparum malaria in Purworejo. 2. To evaluate possible adverse events on the used of AAQ+PQ and DHP+PQ on the treatment of uncomplicated falciparum malaria in Purworejo. The results will provide valuable information regarding the status of ACT regimens and the used of this drug as effective and safe regimen for the population of Purworejo.

\section{MATERIALS AND METHODS}

This is an observational analytic study and was conducted in Purworejo District from December 2010 to August 2011. Subjects were patients with uncomplicated $P$. falciparum malaria who met the inclusion and exclusion criteria ${ }^{15}$. The study was conducted in coordination with District Health Office of Purworejo and local health workers of related Primary Health Centers in Purworejo. Subjects were malaria patients identified during passive or active case finding. Subjects were treated with DHP/Artekin ${ }^{\circledR}$ (Dihydroartemisinin 2-4 $\mathrm{mg} / \mathrm{kg}$ body weight (BW) and Piperaquine $16-32 \mathrm{mg} / \mathrm{kg} \mathrm{BW}$ ); or with AAQ/Arsuamon ${ }^{\circledR}$ (Amodiaquine $10 \mathrm{mg} / \mathrm{kg} \mathrm{BW}$ and artesunate 4 $\mathrm{mg} / \mathrm{kg} \mathrm{BW}$ ); co-administered with Primaquine $(0.75 \mathrm{mg} / \mathrm{kg} \mathrm{BW})$ on the first day as suggested by the Indonesian National Policy. ${ }^{14}$ The administration of AAQ or DHP depended on the availability of either AAQ or DHP in each Primary Health Center. Collection and examination of peripheral blood smear (both thin and thick) were conducted from Day 0 (D0) to D28 for patients being treated with AAQ and D0 to D42 for patients being treated with DHP. Stained blood films were examined by laboratory personnel of a related Primary Health Centers and cross checked by the Department of Parasitology, Faculty of Medicine, Universitas Gadjah Mada, 
Yogyakarta. Patient complaints and clinical symptoms were documented and observed during follow up as well as during blood sample acquisition. Therapeutic responses assessed were Early Treatment Failure and Late Treatment Failure (Late Clinical Failure/ Late Parasitological Failure) as defind in WHO guidelines. ${ }^{15}$ Side effects or adverse event were defined as any clinical sign or symptom that did not exist during first visit (D0) but appeared after, or already existed and were aggravated during the follow up period.

This study was reviewed and approved by Institutional Review Boards for the ethical conduct of research on human subjects at the Faculty of Medicine, Universitas Gadjah Mada, Yogyakarta. Informed consent was collected from subjects before their participation in this study.

\section{RESULTS}

Of the 77 malaria patients recruited, only 46 were followed until day 28 for AAQ and day 42 for DHP. The reasons for that is mostly related with geographical situation, a number of patient refused to be visited or migrated to other place of residency. Patients came from 14 villages spread over 7 subDistricts in Purworejo i.e. Kaligesing, Bener, Bagelen, Pituruh, Pecan, Loano, and Gebang sub-District.

The characteristics of the subjects were shown in TABLE 1. The major complaints of subjects on the commencement of this study are shown in TABLE 2. Fever is the most common clinical manifestation among 46 uncomplicated falciparum malaria patient in Purworejo (91.3\%) follwed by dizziness, headache and muscle pain, however, 4 patient

TABLE 1. The characteristics of uncomplicated falciparum malaria patient in the Purworejo District included in the ACT efficacy study

\begin{tabular}{|c|c|c|c|}
\hline \multirow{2}{*}{ Characteristics } & \multicolumn{3}{|c|}{ Patient treatment regimen } \\
\hline & $\operatorname{AAQ}(n=9)$ & $\operatorname{DHP}(n=37)$ & Total $(n=46)$ \\
\hline \multicolumn{4}{|l|}{ Age } \\
\hline$\cdot 5-15$ & 2 & 6 & 8 \\
\hline - $16-45$ & 4 & 18 & 22 \\
\hline$\cdot \geq 46$ & 3 & 13 & 16 \\
\hline \multicolumn{4}{|l|}{ Sex } \\
\hline - Male & 7 & 18 & 25 \\
\hline - Female & 2 & 19 & 21 \\
\hline \multicolumn{4}{|l|}{ Plasmodium stage } \\
\hline - Trophozoit + gametes & 3 & 9 & 12 \\
\hline - Trophozoit & 6 & 28 & 34 \\
\hline \multicolumn{4}{|l|}{ Parasite density } \\
\hline • $1000-10,000$ & 7 & 22 & 29 \\
\hline • >10.000-50,000 & 2 & 12 & 14 \\
\hline • $>50,000-100,000$ & 0 & 3 & 3 \\
\hline \multicolumn{4}{|l|}{ Axilla temperature $\left({ }^{\circ} \mathrm{C}\right)$} \\
\hline$\bullet \geq 37.5$ & 8 & 34 & 42 \\
\hline • $<37.5$ & 1 & 3 & 4 \\
\hline
\end{tabular}

$\mathrm{n}=$ number of samples; parasite density is the number of asexual parasite per $\mu \mathrm{l}$ blood 
(87\%) did not experience any clinical sign (asymptomatic). Parasite density did not seem to correlate much with fever, 25 out of $29(86 \%)$ patients with parasite density between 1000 10.000 parasite/ul experiencing fever, as well as all patients with higher parasite density (14 and 3 patients with parasite density $>10,000$ 50,000 and 750,000-100,000 respectively). (TABLE 3).

TABLE 2. Clinical symptoms of uncomplicated falciparum malaria patient in Purworejo District involved in the ACT efficacy study conducted from December 2010 to August 2011

\begin{tabular}{lc}
\hline \multicolumn{1}{c}{$\begin{array}{c}\text { Patients' clinical } \\
\text { symptoms }\end{array}$} & $(\mathrm{N}=46) \%$ \\
\hline Fever & 91.30 \\
Dizziness & 91.30 \\
Headache & 89.13 \\
Shivering & 71.74 \\
Anorexia & 63.04 \\
Muscle pain & 78.26 \\
Coughing & 4.35 \\
Vomiting & 15.22 \\
\hline
\end{tabular}

TABLE 3. The present or absent of fever in uncomplicated falciparum malaria patient in Purworejo District involved in the ACT efficacy study conducted from December 2010 to August 2011 according to parasite density

\begin{tabular}{lccc}
\hline $\begin{array}{c}\text { Parasite density } \\
\text { (no. of asexual/ul) }\end{array}$ & \multicolumn{3}{c}{ Symptom of fever } \\
\cline { 2 - 4 } $1000-10,000$ & $25(86 \%)$ & No fever & Total \\
$>10,000-50,000$ & $14(100 \%)$ & $4(14 \%)$ & 29 \\
$>50,000-100,000$ & $3(100 \%)$ & 0 & 14 \\
\hline
\end{tabular}

The percentage of patients that were free of fever following DHP+PQ treatment ( $\mathrm{n}=$ 37) was $41 \%, 76 \%, 89 \%, 97 \%$ on day 1,2 , 3, 7 respectively. All patients were feverfree on day 14. The percentage of patients who were free of asexual parasites was $76 \%$, $95.6 \%$ on day 1 and 2 and all patients (100\%) were free of parasites on day 3 of follow-up
(FIGURE 1). Different results were shown by subjects treated with $A A Q+P Q(n=9)$, i.e. the percentage of patients with free fever is $67 \%$ on day 1 and reached $100 \%$ on day 2 , while the percentage of patients with free asexual parasites is $90 \%$ on the first day and reached $100 \%$ on day 2 (FIGURE 2 ). 


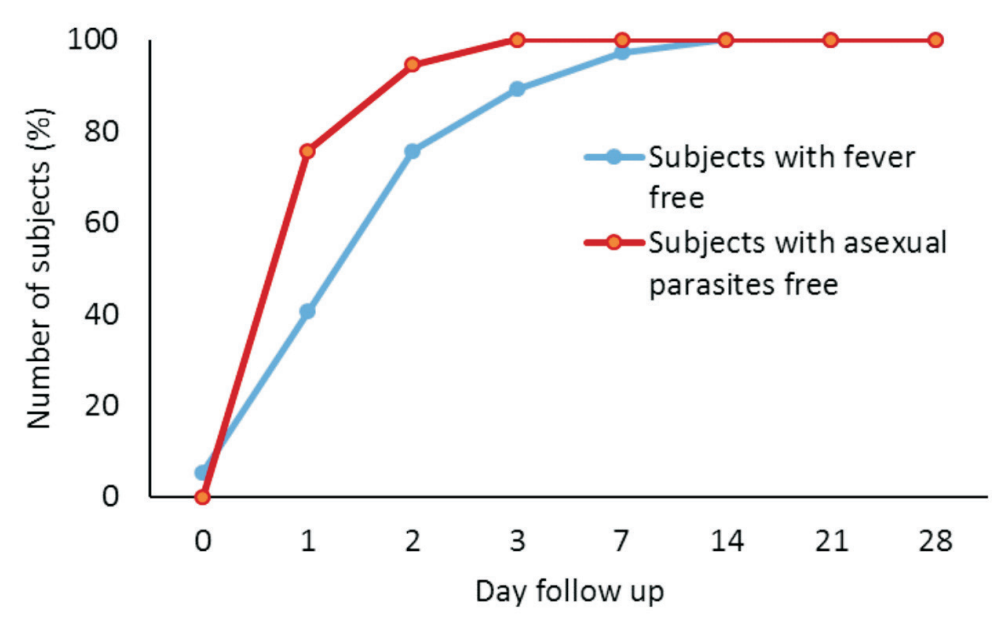

FIGURE 1. The disappearance of fever and asexual parasite in uncomplicated malaria patients following DHP+PQ treatment.

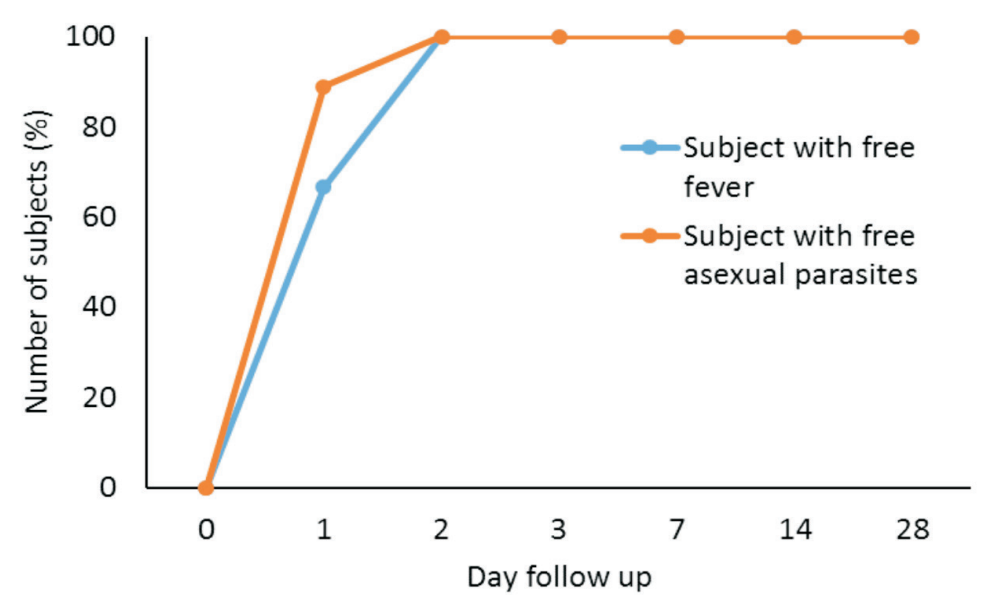

FIGURE 2. The disappearance of fever and asexual parasites in uncomplicated falciparum malaria patients following treatment with $\mathrm{AAQ}+\mathrm{PQ}$.

On the first day patients were recruited in the study, $25 \%$ and $35 \%$ subjects carried gametocytes before the administration of DHP and AAQ respectively. On treatment with DHP+PQ, number of gametocytescarrier patients reduced from $24.32 \%$ on day 0 to $21.62 \%$ and $10.81 \%$ on day 1 and 2 follow- up, and reached $0 \%$ (cleared-up) by the third day follow-up. On treatment with $\mathrm{AAQ}+\mathrm{PQ}$, number of gametocytes carrier patients reduced from $33 \%$ on day 0 to $22 \%$ both on day 1 and 2 follow-ups respectively, and $0 \%$ (cleared-up) on the third day post treatment (FIGURE 3). 
Michael Bhadi Bia et al., Evaluation of artemisinin-based combination therapy (ACT) to uncomplicated falciparum malaria patients in Purworejo District, Central Java, Indonesia

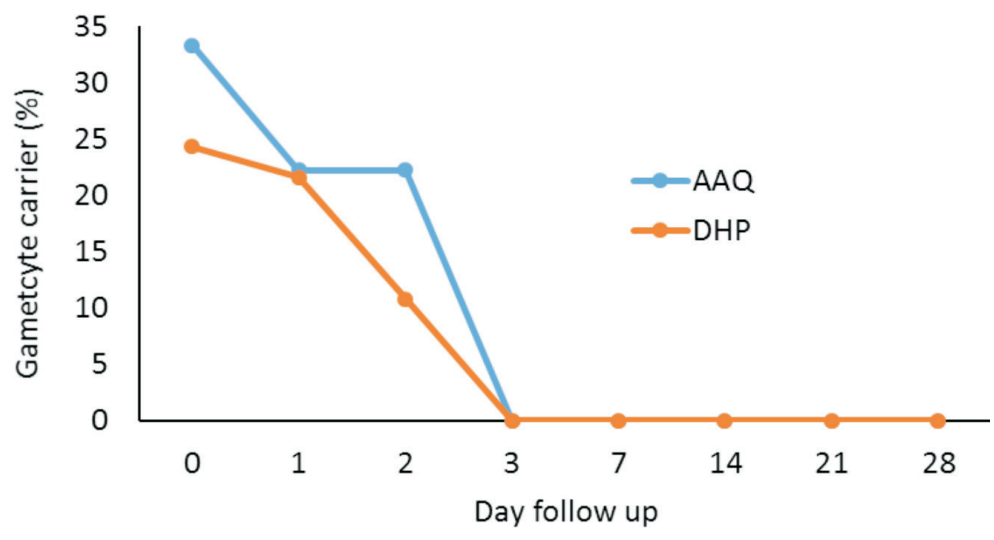

FIGURE 3. The disappearance of gametocyte in P. falciparum-infected subjects treated with $\mathrm{AAQ}+\mathrm{PQ}$ or $\mathrm{DHP}+\mathrm{PQ}$ during follow up.

As shown on FIGURE 4, the clinical symptom of malaria dissapeared following ACT treatment. In group treated with $\mathrm{DHP}+\mathrm{PQ}$, the percentage of subjects have no clinical symptoms was $5 \%, 25 \%, 70 \%, 80 \%$, and $90 \%$ on day $2,3,7,14$ and 21 follow-up. In group treated with $\mathrm{AAQ}+\mathrm{PQ}$, all subject still have clinical symptoms until day 3 followup, and afterwards, the percentage of subjects with clinical symptoms began to decrease on day 7 and 14 , to $40 \%$, and $70 \%$ respectively (FIGURE 5). All subjects were free of clinical symptoms on day 28 for DHP and on day 21 for AAQ treatment. The dominant clinical signs were headache, dizziness and muscle pain for subjects treated with DHP+PQ and headache, dizziness and loss of appetite for subjects treated with AAQ. Both regiments showed neither early or late treatment failure (TABLE 4).

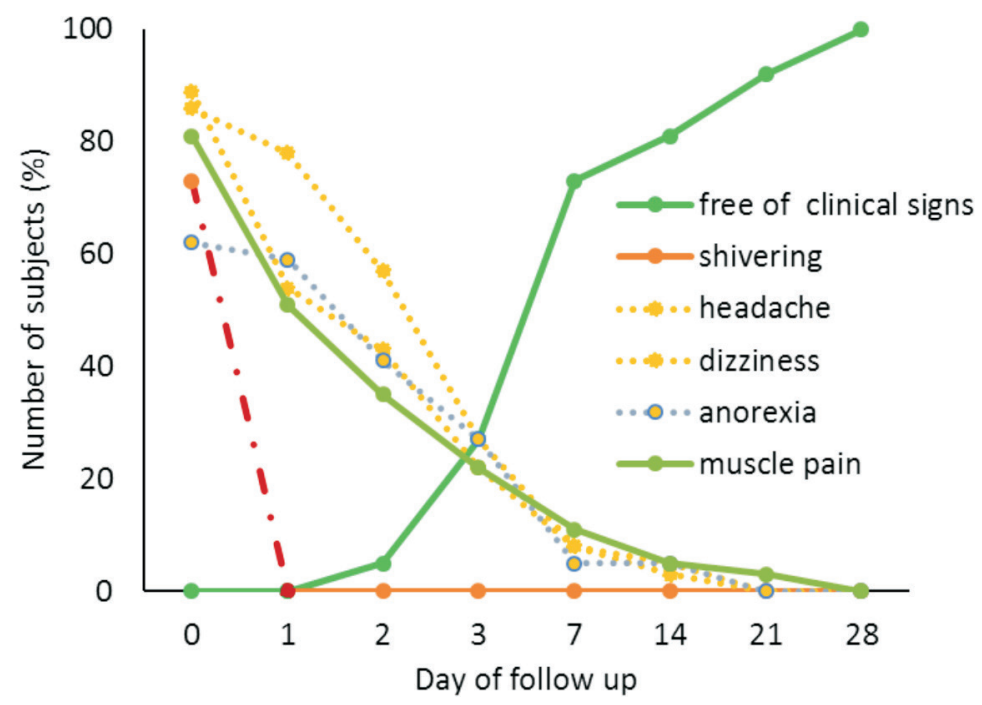

FIGURE 4. The disappearance of clinical symptoms in uncomplicated falciparum malaria patients treated with DHP + PQ during follow up. 


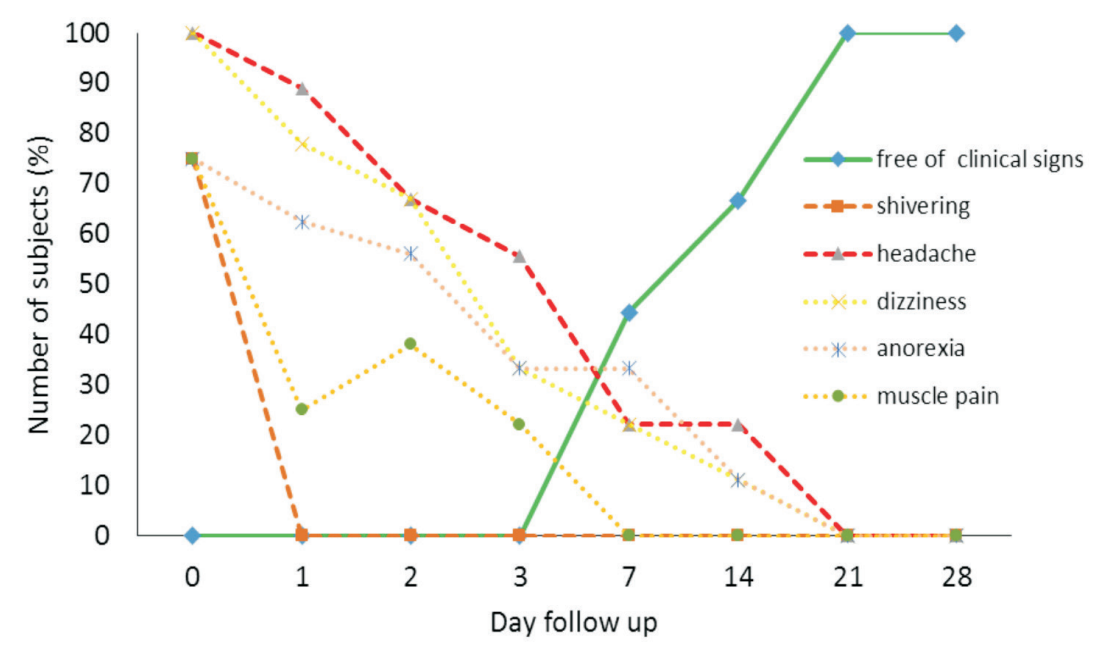

FIGURE 5. The disappearance of clinical symptoms in uncomplicated falciparum malaria patients treated with $\mathrm{AAQ}+\mathrm{PQ}$ during follow up.

TABLE 4. The result of the evaluation of ACT treatment to uncomplicated falciparum malaria patient in the Purworejo District from December 2010 to August 2011.

\begin{tabular}{lcccccc}
\hline \multirow{2}{*}{ Drugs } & \multicolumn{5}{c}{ Status of Resistance (\%) } & \multirow{2}{*}{ Total } \\
\cline { 2 - 6 } & Sensitive & Early RI & Late RI & R II & R III & \\
\hline DHP+PQ & 100 & 0 & 0 & 0 & 0 & 100 \\
AAQ+PQ & 100 & 0 & 0 & 0 & 0 & 100 \\
\hline Total & 100 & 0 & 0 & 0 & 0 & 100 \\
\hline
\end{tabular}

On treatment with $\mathrm{DHP}+\mathrm{PQ}$, side effects disappeared by D-1 in 5\% subjects. This percentage increased to $25 \%$ on $\mathrm{D}-3$, and to $75 \%$ on D-7. All subjects were free of side effects on D-28 (FIGURE 6). The dominant side effects with DHP+PQ treatment were nausea, stomach pain and dark urine. A small proportion of subjects (3\%) complained of discomfort while breathing after the administration of DHP+PQ. All subjects complained of having adverse events with $\mathrm{AAQ}+\mathrm{PQ}$ from $\mathrm{D} 1$ to $\mathrm{D} 3$. On D-7, $+50 \%$ subjects were free of adverse events and this percentage increased on D-14 (80\%) and all subjects $(100 \%)$ were free of adverse events on D-21 (FIGURE 6). The dominant adverse events in order of occurrence were nausea, dark urine, stomach pain, vomit, and discomfort while breathing. 
Michael Bhadi Bia et al., Evaluation of artemisinin-based combination therapy (ACT) to uncomplicated falciparum malaria patients in Purworejo District, Central Java, Indonesia

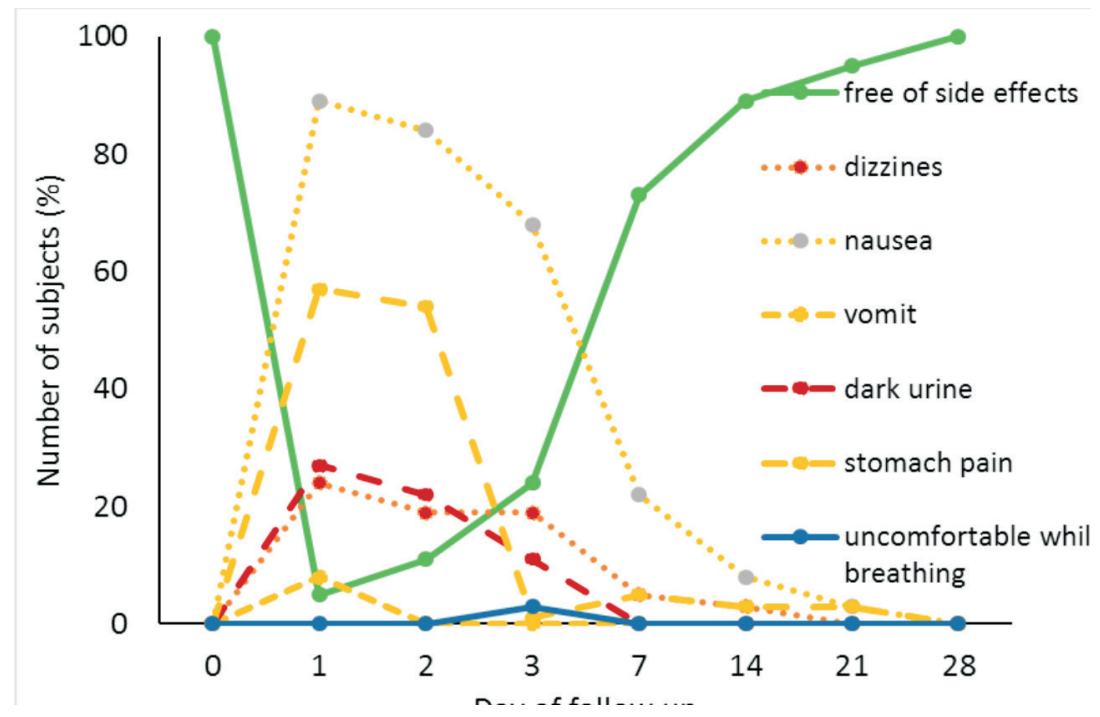

FIGURE 6. Adverse events seens in patients treated with DHP+PQ during follow up

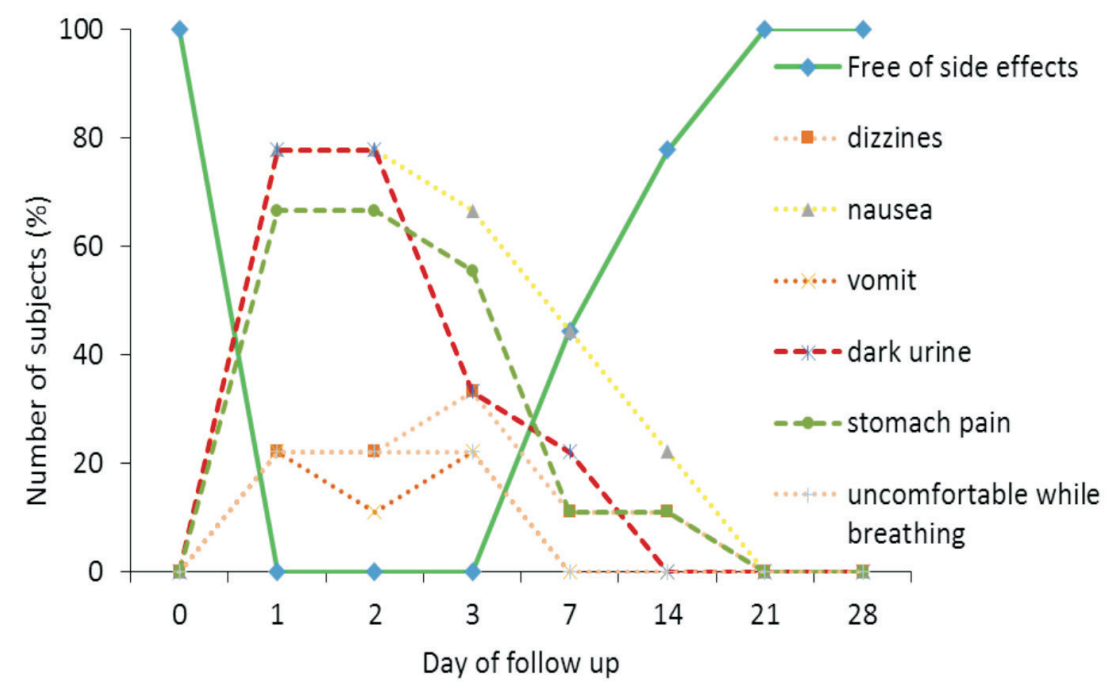

FIGURE 7. Side effects seens in patients treated with AAQ + PQ during follow up

\section{DISCUSSION}

From 46 subjects observed in this study, $48 \%$ were in productive age (16-45 years old). These probably related with the chance of getting the infection since people in this group of age are more active compared to childhood and elderly. The majority of malaria patient in Purworejo were symptomatic with predominat symptom of fever, diziness and muscle pain and only less than ten percent were asymptomatic. These clinical picture are representing characteristic of malaria patient from low endemic areas where the transmission are low and may be seasonal which do not stimulate effective immune 
responses and therefore symptomatic malaria patients must be common in this such low endemic areas. These condition are also in accordance with the low seroprevalence and antibody levels of population in Purworejo. ${ }^{16}$ Asymptomatic patient were expectedly be found in area of higher endemicity such as in Lampung ${ }^{17}$, where higher level of malaria transmission will stimulate higher antibody responses, resulting in higher seroprevalence and higher antibody level in the serum ${ }^{16}$ that might suppressed the clinical manifestation of the diseases.

The presence of subject with gametocytes $(26 \%)$ on day 0 probably suggesting that transmission might be still in progress during the study since Purworejo was a receptive areas where Anopheles mosquito vector are always available in most of the time ${ }^{8}$, readily transmits any gametocytes within the blood circulation of the nearby population. The factor that might stimulate the differenciation to gametocytes might varies such as the host immune responses, oxidative stress or other condition that make the parasite in uncomfortable condition. ${ }^{18}$ The presence of gametocyte in the blood circulation of malaria patient must be take as highly priority of attention since it is critical for transmission to other people. Anti gametocytocidal drug must be given and prevention to mosquito bite are also very essential.

In this study both DHP+PQ and AAQ+PQ treatment resulted in the rapid clearance of both asexual and sexual form of the parasite by day 3 of the follow-up. ACT is known as a potent blood schizonticides which also have an anti gametocidal effect but only against immature gametocytes, and therefore addition of Primaquine on the first day of ACT treatment are still essential to kill the mature gametocytes. ${ }^{19}$ Efficacy study of DHP treatment without PQ had been carried-out in Kalimantan and Sulawesi by Siswantoro et $a .^{20}$ and reported that in those study gametocytes were still detected on D-28 of the follow-up. The similar result was shown when using Artemisinin-mefloquine without PQ in Thailand. ${ }^{21}$ The effect of primaquine on the treatment of malaria using ACT was also shown in Lampung by Inge et al. ${ }^{22}$ and the result indicated that the addition of primaquin may fastened the gametocyte clearance from the blood circulation as compared to ACT whithout prmaquine. The efficacy of DHP+PQ and AAQ+PQ on the treatment of uncomplicated malaria patient in the Purworejo District indicated that these regiment are still sentitive, no early nor late treatment failure. Although the efficacy of $\mathrm{DHP}+\mathrm{PQ}$ and $\mathrm{AAQ}+\mathrm{PQ}$ in this study seems still promising, further study that includes more subject at least 50 subjects as recommended by WHO are highly suggested to make statistically significant conclusion.

Despite the effectiveness of $\mathrm{DHP}+\mathrm{PQ}$ and $\mathrm{AAQ}+\mathrm{PQ}$ in the clearance of sexual and asexual parasites, this study also showed that both regiments also rapidly reduce most of the clinical symptoms appeared on the patient with more intensive in DHP+PQ as compared to $A A Q+P Q$, except for fever which was last longer until day 14 in DHP+PQ treated patients. Shiver was also common symptom appeared in malaria patient in Purworejo, however, this symptom rapidly dissappeared on the following day of the first ACT treatment. Although both treatments also causing some adverse events, i.e. symptoms that initially absent but appeared following treatment or initially present and than agravated following treatment. The major adverse events arosed were nausea, stomach pain and dark urine. These adverse events were less and minimal in DHP treated patients. Furthemore, they also dissapear faster in DHP treated patients. 
Similar adverse events during the used of DHP was also repoted by Hasugian et $a l .{ }^{6}$ during treatment against multidrugsresistant malaria in Papua suah as nausea, vomiting, and anorexia. These adverse events diminished on D-7, and were also milder and better tolerated than those treated with AAQ. Vomiting, stomach pain and discomfort during breathing/dyspnea was also been reported with DHP treatment ${ }^{23,24}$ but there was no evidence of the ECG changes. ${ }^{23}$ Adverse events seen during and after treatment needs to be considered as an important factor that might contribute to patient compliance for malaria drugs regimens. ${ }^{25}$ The fact that some subjects complained dark urine during treatment or follow-up days suggested that some subjects might experienced hemolysis as a results of enzyme disorder condition (G6PD).

\section{CONCLUSION}

Treatment of uncomplicated falciparum malaria patients using $\mathrm{DHP}+\mathrm{PQ}$ and $\mathrm{AAQ}+\mathrm{PQ}$ is successful in clearing of the asexual parasites in the Purworejo District with no Early nor Late Treatment Failure, and therefore no artemisinin resistance is observed. The coadministration of primaquine onto these regiments is useful in gametocyte clearance adding the benefit of possibly blocking the transmission. It is recommended that $\mathrm{DHP}+\mathrm{PQ}$ or $\mathrm{AAQ}+\mathrm{PQ}$ should still be used in the Purworejo District realizing that adverse events may be an issue with compliance. Dark urine that found in some subjects demands further study on the prevalence of G6PD deficient in this region.

\section{ACKNOWLEDGEMENTS}

We thank the District Health Officer of Purworejo and its staff, Heads of PHC and malaria workers that were involved in this study. This project has been funded in part with funds from the Bill and Melinda Gates Foundations under Grant No. 45114 (Malaria transmission Consortium).

\section{REFERENCES}

1. World Health Organization. Susceptibility of Plasmodium falciparum to antimalarial drugs: Report on global monitoring 1996-2004. Geneva Switzerland: WHO Press, 2005.

2. Kementrian Kesehatan, RI. Epidemiologi malaria di Indonesia. Buletin Jendela Data dan Informasi Kesehatan 2011; I(1):1-16.

3. Borst $\mathrm{P}$ and Oullette M. New mechanisms of drug resistance in parasitic protozoa. Ann rev Microbio 1995; 49:427-60. http://dx.doi. org/10.1146/annurev.mi.49.100195.002235

4. World Health Organization. Global plan for artemisinin resistance containment. Geneva. Switzerland: WHO Press, 2011.

5. Afonso A, Hunt P, Cheesman S, Alves AC, Cunha CV, do Rosario V, et al. Malaria parasites can develop stable resistance to artemisinin but lack mutations in candidate genes atp6 (Encoding the sarcoplasmic and endoplasmic reticulum $\mathrm{Ca}$, 2ATPase), tctp, mdr1, and cg10. Antimicrob Agents Chemother 2006; 50: 480-9.

http://dx.doi.org/10.1128/AAC.50.2.480489.2006

6. Hasugian AR, Purba HLE, Kenangalem E, Wuwung RM, Ebsworth EP, Maristela L, et al. Dihydroartemisinin-piperaquine versus artesunate-amodiaquine: superior efficacy and post-treatment prophylaxis against multidrug-resistant Plasmodium falciparum and Plasmodium vivax malaria. Clinic Infect Dis 2007; 44(8): 1067-74. http://dx.doi.org/10.1086/512677

7. Kusriastuti R. Towards malaria elimination in Indonesia. Executive Board Meeting, ACT Malaria. Vientiene, 16 - 18th Maret 2009. 
8. Darundiati YH. Analisis faktor-faktor resiko malaria di daerah endemis dengan pendekatan spasial di Kabupaten Purworejo [Tesis]. Semarang: Universitas Diponegoro; 2003.

9. Kuswantoro. Situasi malaria di Purworejo tahun 2006-2010 dan strategi percepatan pencapaian eliminasi. Makalah dipresentasi-kan pada Simposium Desiminasi Kondisi Malaria di Purworejo. Tanggal 1 Maret 2011. Purworejo, 2011.

10. Linggi BMD, Tjokorosonto S, Pramono D. Efikasi kombinasi klorokuin-primakuin dan sulfadoksin pirimetamin-primakuin terhadap malaria falsiparum dan dampaknya terhadap siklus Sporogoni di Kecamatan Pituruh Kabupaten Purworejo. Sain Kesehatan 2003; 16(2): 285-99.

11. Laihad FJ dan Arbani PR. Situasi malaria di Indonesia dan penanggulangannya. Malaria dari Molekuler ke Klinis. eds. P.N.Harijanto. EGC: Jakarta, 2009:1-16.

12. Lederman ER, Maguire JD, Sumawinata IW, Chand K, Elyazar I, Estiana L, et al. Combined chloroquine, sulfadoxine/pyrimethamine and primaquine against Plasmodium falciparum in Central Java. Malaria J 2006; 5:108. http://dx.doi.org/10.1186/1475-2875-5-108

13. Kusumaningsih M. Uji Efikasi kombinasi artesunat-amodiakuin dibandingkan dengan sulfadoksin-pirimetamin dan primakuin pada penderita malaria falciparum tanpa komplikasi di Kabupaten Purworejo [Tesis]. Yogyakarta: Universitas Gajah Mada; 2005.

14. Departemen Kesehatan R.I. Pedoman penatalaksanaan kasus malaria di Indonesia. Jakarta: Direktorat Jenderal Pengendalian Penyakit \& Penyehatan Lingkungan Departemen Kesehatan RI, 2009.

15. World Health Organization. Assessment and Monitoring of Antimalarial Drug for the Treatment of Uncomplicated Falciparum. Geneva Switzerland: WHO Press, 2003.
16. Supargiyono S, Bretscher MT, Wijayanti MA, Sutanto I, Nugraheni D, Rozqie R, et al. Seasonal changes in the antibody responses against Plasmodium falciparum merozoite surface antigens in areas of differing malaria endemicity in Indonesia. Malaria J 2013; 12:444. http://dx.doi.org/10.1186/1475-2875$12-444$

17. Sutanto I, Endawati D, Ling LH, Laihad F, Setiabudy R, and Baird JK. Evaluation of chloroquine therapy for vivax and falciparum malaria in southern Sumatra, western Indonesia. Malaria J 2010; 9:52. http://dx.doi. org/10.1186/1475-2875-9-52

18. Josling GA and Llinás M. Sexual development in Plasmodium parasites: knowing when it's time to commit. Nat Rev Microbiol 2015; 13(9):573-87. http://dx.doi.org/10.1038/nrmicro3519

19. Peatey CL, Leroy D, Gardiner DL, Trenholme KR. Anti-malarial drugs: how effective are they against Plasmodium falciparum gametocytes? Malaria J 2012; 11:34. http:// dx.doi.org/10.1186/1475-2875-11-34

20. Siswantoro H, Hasugian AR, Avrina R, Risniati Y, Tjitra E. Efikasi dan keamanan dihidroartemisinin-piperakuin (DHP) pada penderita malaria falsiparum tanpa komplikasi di Kalimantan dan Sulawesi. Media Litbang Kes 2011; 21(3): 135-44.

21. Tangpukdee N, Krudsood S, Srivilairit S, Phophak N, Chonsawat P, Yanpanich W, et al. Gametocyte clearance in uncomplicated and severe Plasmodium falciparum malaria after artesunate-mefloquine treatment in Thailand. Korean Parasitol 2008; 46 (2): 65-70. http:// dx.doi.org/10.3347/kjp.2008.46.2.65

22. Sutanto I, Suprijanto S, Kosasih A, Dahlan MS, Syafruddin D, Kusriastuti R, et al. The Effect of primaquine on gametocyt development and clearance in the treatment of uncomplicated falciparum malaria with dihydroartemisinin-piperaquine in South Su- 
matra, Western Indonesia: An open-label, randomized controlled trial. Oxford J Clin Infec Dis 2012; 44(8):1067-74. http://dx.doi. org/10.1093/cid/cis959

23. Sinclair D, Gogtay N, Brand F, Olliaro PL. Artemisinin-based combination therapy for treating uncomplicated Plasmodium vivax malaria. Cochrane Database of Systematic Reviews 2011; 7:CD008492. http://dx.doi. org/10.1002/14651858.CD008492.pub2
24. Poespoprodjo JR, Fobia W, Kenangalem E, Lampah DA, Sugiarto P, Tjitra E, et al. Dihydroartemisinin-piperaquine treatment of multidrug resistant falciparum and vivax malaria in pregnancy PLOS 2014; 9(1): e84976.

http://dx.doi.org/10.1371/ journal. pone. 0084976

25. Nosten F, White NJ. Artemisinin-based combination treatment of falciparum malaria. Am J Trop Med Hyg 2007; 77(6 Suppl):181-92. 